\title{
Framing, overflowing, and fuzzy logic in educational selection: Zurich as a case study
}

\author{
Itta Bauer \\ Department of Geography, University of Zurich, 8057 Zurich, Switzerland \\ Correspondence: Itta Bauer (itta.bauer@geo.uzh.ch)
}

\begin{abstract}
Received: 24 January 2017 - Revised: 5 December 2017 - Accepted: 10 December 2017 - Published: 26 January 2018
Abstract. This paper uses the concepts of "framing and overflowing" (Callon, 1998) and "fuzzy logic" (Zadeh, 2015) to show the application and relevance of critically examining educational selection beyond the particular local context. It examines the empirical example of the central entrance examination procedure to grammar schools in the canton of Zurich. The main argument illuminates the widely neglected grey zones and the fuzzy logic lying at the heart of the selection machinery for higher education. This article elaborates fruitful links between the local case study and international discourses on the geography of education and educational research. It thus shows how a socio-material approach may build bridges not only between international and national educational discourse and local practice but also between academic research and a socio-political engagement that cares about young people's educational realities and futures.
\end{abstract}

\section{Introduction}

One broad field of interest within social, geographical, and educational research concerns "transitions". This has generated an extremely rich and quite heterogeneous body of literature. The structures, processes, and experiences of transitions within both comprehensive and selective education systems in Europe have been discussed from various theoretical standpoints. One salient issue related to transitions within formal education is that of selection: is it possible to select students fairly according to their differing abilities? Which criteria are relevant to granting students access to higher education? At what age is educational selection most appropriate? At the heart of these questions is the wider issue of social justice or the reproduction of social inequalities through public institutions of education. Whereas these questions of principle have been inspirational sources for many disciplines, I focus here on the research on educational selection and geographies of education in particular.

\section{Research on educational selection and geographies of education}

The issue of educational selection unites several strands of research: established and powerful discourses on rational- choice approaches to selection (Ditton, 2010; Maaz et al., 2006), debate on the reproduction of social inequalities (Becker, 2010, Bourdieu and Passeron, 2011; Henz and Maas, 1995), and discussion of the emergence of global educational governance through PISA, TIMSS, and other tests (Meyer and Benavot, 2013).

In relation to the issue of educational selection, I identified two lines of transdisciplinary discourse: the first of these lines is the discourse on the inequality of opportunity in education. The debate is mainly focused on the threshold between primary and secondary education and is dominated by rather contrary positions. On the one hand, researchers draw on rational-choice approaches to explain a meritocratic education ideal that makes use of selective procedures in education to reproduce different social milieus in Western societies (Baumert et al., 2009; Becker and Hadjar, 2009; Boudon, 1974; Maaz et al., 2006). On the other hand, critical approaches either advocate the right of children and young people from socially disadvantaged and migration backgrounds to good education (e.g. Becker, 2010; Becker and Lauterbach, 2004; Brake and Büchner, 2012; Fibbi et al., 2011; Imdorf, 2011) or contest the "illusion of equality of opportunity" in education altogether (Bourdieu and Passeron, 2011). This stronger position sees as false the notion of equal out- 
comes on the grounds of equal starting points. This perspective or socio-political dogma veils, legitimizes, and reinforces the existing inequality of chances, because children start from very different educational backgrounds. Consequently, they face different prospects, and this needs to be addressed by a politics of inequality that advantages the hitherto disadvantaged at the social and educational margins. However, transferring this claim from theoretical discourse to educational realpolitik presents quite a challenge. Furthermore, Tim Butler and Chris Hamnett (2007) add a geographical aspect to this argument: "The social and political dangers of exclusion and polarization for large swathes of the populations of the currently developed nations and the consequences of these for social cohesion serve to explain why this issue is moving up the social and political agenda" (Butler and Hamnett, 2007:1162). They argue that the growth of the middle classes in Western countries increases the pressure for educational achievement on the next generation, who may even struggle to hold their parents' class positions.

The second line of discourse concerns educational selection seen not as a system of social reproduction but rather as a process that is crucial to young people and their families. From this perspective, educational selection has been studied as one of the key temporal and spatial changes in young people's lives. Research in this field has examined the diverse challenges that young people face in the global North and South. These include growing aspirations and increasing pressure on young people and their families to manage lifecourse transitions in neoliberal working environments with precarious job prospects at all levels of educational training (e.g. Jeffrey and Dyson, 2008; Johnson-Hanks, 2002; Punch, 2002; Morrow, 2013; Vasarik Staub, 2015). A range of theoretical and empirical perspectives have proved useful in capturing young people's present educational realities and future perspectives (Brown et al., 2012; Ecclestone et al., 2010; Hörschelmann, 2011; Skelton, 2002; Valentine, 2003). The last 10 years have seen a distinct rise not only in the number of research papers but also in the diversity of research interests within the broad field of geographies of education. This trend has been strengthened by children's and young people's geographers, who have focused on the "social geographies of education", including the educational aspirations of families and young people (Collins and Coleman, 2008; Grant, 2017; Holloway et al., 2011), and "informal education, childhood and youth" (Mills and Kraftl, 2014). However, only a limited body of literature examines the intersection of transitional aspects and segregation in formal schooling by applying both quantitative (e.g. Harris, 2012; Hamnett and Butler, 2011) and qualitative methodologies (Hollingworth et al., 2011). This article contributes to both educational research and geographies of education. In the theoretical section of the article, I present a novel conceptual framing of educational selection that draws on socio-material approaches to education (e.g. Fenwick and Edwards, 2010).
In contrast to established models of educational selection conveying the belief in a meritocratic organization of society in Europe and Switzerland (Baeriswyl, 2015; Becker and Hadjar, 2009; Maaz and Neumann, 2014; Neuenschwander, 2014), this article is written from a socio-material perspective on the geography of education. To develop this perspective, I use actor-network theory (ANT) and assemblage theories (Callon, 1986; Latour, 1996; Law, 1999). These ideas have been applied by educational researchers with diverse interests including a Deleuzian assemblage approach, teacher education programmes, deconstructing objectivized statistical pursuits, and the political implications of PISA (e.g. Beighton, 2012; Gorur, 2011, 2014). Young people's geographers and geographers of education have also found sociomaterial approaches useful for enriching the theoretical and methodological debates in relation to formal and informal contexts of learning (Fenwick and Edwards, 2010; Horton and Kraftl, 2006; Jöns, 2006; Rautio, 2013). Crossing the boundaries between university and school, researchers have initiated new debates that have helped to read and analyse everyday classroom encounters through the lenses of ANT and socio-material approaches. Their studies have elaborated the importance to researchers and teachers alike of critically questioning the use of things such as books, web pages, models, and films as co-productive educational tools in contexts of learning (e.g. Bauer, 2015; Fox, 2009; Verran, 1999).

I use the concepts of "framing and overflowing" (Callon, 1998) and "fuzzy logic" (Zadeh, 2015) to show the relevance of considering the central entrance examination procedure to grammar schools in the canton of Zurich beyond the narrow local context. In so doing, I draw wider connections to debates in educational research and geographies of education. The main argument of this article elaborates diverse aspects of the widely neglected grey zones and the fuzzy logic at the heart of the selection process.

Before doing this, it is important to explain the local context in which the central entrance examination to grammar schools in the canton of Zurich is used as a tool for selection at the threshold between primary and secondary education.

\section{Context: educational selection in Switzerland and the introduction of ZAP in the canton Zurich}

Switzerland and its German-speaking neighbours have a long tradition in a stratified education system that bifurcates students after 4 to 6 years of primary school to either grammar schools (this term is used here to translate Mittelschulen, Maturitätsschulen, and Gymnasien in the German-speaking part of Switzerland) or to secondary schools (i.e. Sekundarschulen). Although there have been some initiatives for comprehensive schooling (Gesamtschulen), the academically selective, university-preparatory grammar school is not in danger of disappearing any time soon (see Schneider and Tieben, 2011). On the contrary, it is widely supported. In 
Switzerland, as in Germany and Austria, grammar schools have constantly expanded in numbers since the 1960s. Whereas in 1960 only $3.8 \%$ of the population in Switzerland graduated from a grammar school (receiving unrestricted university access by obtaining a school leaving certificate, called a Matura), the equivalent figure had increased by 1980 to $10.6 \%$ in 1980, by 2000 to $17.8 \%$, and by 2016 to $20.2 \%$ (Bundesamt für Statistik, 2017a; Oelkers, 2008). The expansion of grammar schools is also reflected by the number of graduates. In 2000, 15027 students who left Swiss grammar schools with a Matura, compared to 186298 years later, a level that has remained steady ever since (Bundesamt für Statistik, 2017b). This trend is even stronger in the largely urban canton of Zurich: in 2000, 1735 students graduated from grammar school; in 2016, the equivalent figure was 2957 (Bildungsdirektion Kanton Zürich, 2001, 2017).

The education system in Switzerland, with its dual focus on academic and vocational education, provides the opportunity for motivated and gifted students who attended secondary school and started apprenticeships to take additional courses (at Berufsmaturitätsschulen), for which successful attendees are rewarded with a Berufsmaturität. This certificate is a key qualification and a first step towards tertiary education for such young people. The numbers of students graduating from occupational training (including training on the job and advanced courses in subjects such as languages and mathematics) steadily increased from 6475 in 2000 to 14397 in 2016 across Switzerland and from 1172 (2000) to 2312 (2016) in the canton of Zurich (Bundesamt für Statistik, 2017b). ${ }^{1}$ On the one hand, the numbers have shown a move towards higher education in Switzerland that reflects the general trend in countries of the global North ${ }^{2}$. On the other hand, a political dispute has arisen over regional differences between the graduation quotas of the 26 cantons in Switzerland. The graduation quota (Maturitätsquote) shows the percentage of students who have graduated from school with a certificate that enables them to continue education at tertiary level (Bundesamt für Statistik, 2017a, translated by the author). The graduation quotas from grammar schools of 2006 and 2016 across different Swiss cantons range from $13 \%$ in the cantons of St. Gallen and Uri to about $30 \%$

\footnotetext{
${ }^{1}$ In addition to the high numbers of students graduating from school or professional training with Berufsmatura, there are other educational tracks within specific key areas of training (e.g. in health and natural sciences or communication and ICT) available in Switzerland, resulting in Fachmaturitäten (2730 graduates in 2016), Fachmittelschulausweise (3991 graduates in 2016), advanced Berufsmatura (also termed Passarelle) (959 graduates in 2016), and international baccalaureate (680 graduates in 2016; Bundesamt für Statistik, 2017b).

2 "At $30 \%$ (2011), the Swiss Matura rate (sum of Matura from grammar schools, Berufsmaturitätsschulen, and Fachmaturitätsschulen) is comparatively low compared to international levels of education; for instance, in OECD countries, this average rate exceeds $60 \%$ " (SKBF, 2014:145, translated by author).
}

in the cantons of Basel-Stadt, Ticino, and Geneva (SKBF, 2014:144; Bundesamt für Statistik, 2017a). In selective educational systems, such as in Switzerland, it is not only the number of graduates that is important. Additionally, how students are granted access to grammar school and thus have the chance to aspire to higher education has been a political hot potato in Switzerland for a long time.

The year 2007 is an important landmark in the educational landscape of the canton of Zurich. Until then, each grammar school was able to select students according to their marks in primary school and the results of an entrance test that the students took at their favoured grammar school. Each school took direct responsibility for the preparation, performance, and marking of its own entrance test. As a consequence, each grammar school accepted as many successful students as the school was willing to cope with. This situation started to change in 2005, when the head of the cantonal Bildungsdirektion, the administrative division of local government responsible for the school system (Regine Aeppli, Social-Democratic Party), introduced a reform of the Mittelschulgesetz which would regulate all publicly funded grammar schools in the canton of Zurich. The core element of this reform was the introduction of a centrally organized entrance test (called the Zentrale Aufnahmeprïfung, subsequently abbreviated as ZAP). This written test in mathematics and German was to be obligatory for all grammar schools. The reform was effective from the year 2007, starting with Langzeitgymnasium (6-year grammar schools) and extending to Kurzzeitgymnasium (4-year grammar schools) a year later. Students of both types of grammar school complete their secondary education with a Matura, granting free access to higher education.

The Bildungsdirektion gave two main reasons for this ambitious initiative which were widely circulated by the local media: first, the local government wanted to end public rumours that grammar schools varied greatly in their treatment of potential new students. This gave rise to speculation that the share of students attending grammar school in well-off areas in Zurich was disproportionally high compared to poorer urban areas and elsewhere in the agglomeration of the canton (Baumann, 2007). The Bildungsdirektion decided that, from 2007 on, every student had to pass the same test procedure to qualify for the prestigious education at a grammar school. Second, the introduction of one test for all was intended to increase the comparability of test results at grammar schools in the canton. Therefore, the Bildungsdirektion hoped that the introduction of the ZAP would effectively put an end to speculation about unequal opportunities in education (Schneebli, 2007).

The canton of Zurich is a particularly interesting place to study selection processes because this complete overhaul of the regulations granting access to grammar schools through the introduction of ZAP has not led to any public uproar, general protest, or substantial critique. Viewed from the outside, this may be rather surprising, especially because both 
local media coverage and educational research (Eberle, 2013; Gymnasialer Mittelschulbericht, 2014; Oelkers, 2008) have been discussing the test procedures, the various amendments to the test, and the annual results in rich detail. Nonetheless, the introduction of the ZAP has rarely been considered anything other than an inevitable fact.

\section{Empirical sources}

The main research purpose of this article is to illuminate and elaborate the widely neglected grey zones and the fuzzy logic at the heart of the selection machinery for higher education. The theoretical argument of the paper is informed by a longterm, qualitative content analysis of local media that includes daily and weekly newspapers (Tagesanzeiger, Neue Zürcher Zeitung, various regional papers in the canton of Zurich, 20 Minuten $^{3}$, Blick $^{4}$, WOZ - Die Wochenzeitung $\left.{ }^{5}\right)$ and publications of local and federal education reports (e.g. press releases, statistics, reports by Bildungsdirektion Zürich, Bildungsbericht Schweiz, 2014).

First, the data covering the years from 2002 to 2017 were collected in a database using MaxQDA 11, a software for qualitative and mixed methods research. I used qualitative content analysis (Mayring, 2010; Krippendorff, 2013; Schreier, 2012) as a "hermeneutic procedure of text interpretation" to assign abstract categories to text passages with particular contents (e.g. issues, claims, problem definitions; see Kutter and Kantner, 2012:7). Next, the data was processed and coded in more detail. This process involved several runs of close reading and resulted in a code notebook that included both concept-driven codes (inspired by theory about transition, social inequalities and selection) and datadriven codes (drawing in situ codes from the texts, e.g. emotions, ZAP results, boys). Also, "successive summarizing" (Mayring, 2010) of particular codes were helpful in elaborating highly relevant issues (e.g. introducing ZAP) and recurring contradictions in the data concerning a particular issue (e.g. equality of chances).

The theoretical arguments of the paper are therefore developed and enriched by drawing on this database. The empirical examples presented in this article have all been selected from the Tagesanzeiger, which is the most read

\footnotetext{
${ }^{3}$ With a daily print run of 442994 , this free tabloid-style newspaper is the most read newspaper in the German-speaking part of Switzerland, (http://www.schweizermedien.ch/SCHM/ media/SCHMMediaLibrary/Statistiken/Statistiken2016_1/16_ Tageszeitungen-Sonntagszeitungen-2016_1.pdf, 25.8.2017)

${ }^{4}$ This free tabloid newspaper has a daily print run of 143499 and is one of the most read newspapers in Zurich (http://www.schweizermedien.ch/SCHM/media/ SCHMMediaLibrary/Statistiken/Statistiken2016_1/16_

Tageszeitungen-Sonntagszeitungen-2016_1.pdf, 25.8.2017).

${ }^{5}$ This is an independent, national, critical weekly paper; in 2016 , it had an annual print run of 16501 and about 107000 readers (https://www.woz.ch/info/woz, 25.8.2017).
}

(460 000 readers) daily newspaper in Zurich ${ }^{6}$. Therefore, it is an excellent source from which to follow interlinked thematic threads such as educational selection and transitions, inequality of chances, and ZAP procedures and the various debates about educational transition and selection.

\section{Socio-material frameworks: framing, overflowing, and fuzzy logic in educational selection}

One purpose of this article is to show how a socio-material reading of educational selection frames an understanding of this process from a different perspective and thus may help to elaborate arguments for a more engaged involvement in this issue. For this purpose, I draw on ANT and assemblage theories, a strand of research that has been developed by scholars such as Annemarie Mol, Bruno Latour, John Hassard, John Law, Marianne de Laet, and Steve Woolgar. In ANT and its applications in education (Fenwick and Edwards, 2010; Fox, 2009; Gorur, 2011; Verran, 1999), I found an approach that broadens the established binary focus in education on either objects (e.g. structures, institutions, benchmarks) or subjects (e.g. teachers, students, families). ANT and assemblage theories led me to question this binary thinking generally and ask different questions. To give two examples, how can educational selection be framed as an assemblage that draws in both social and material things, references, and actors? How is educational selection enacted and performed by human and non-human actors? This theoretical perspective is particularly suited to shedding light on diverse entanglements of human and non-human actors, associations of material and immaterial, emotional and affective, extraordinary and mundane, and stable and ephemeral things and phenomena. This fresh perspective on a well-studied terrain may contribute ideas that help to take the discourse on educational selection further. Starting from the concepts of framing and overflowing (Callon, 1998), I develop this theoretical argument using examples from my empirical study of the selection processes from primary to upper secondary education in the canton of Zurich.

\subsection{Framing and overflowing}

Starting from the concept of "frame" that Goffman elaborated in the study of interpersonal relationships and negotiations of meaning (1974), Callon explains that actors agree "on the frame within which their interactions will take place and on the courses of action open to them" (Callon, 1998:249).

The frame establishes a boundary within which interactions $(. .$.$) take place more or less inde-$

\footnotetext{
${ }^{6}$ In 2016, Tagesanzeiger had a print run of 147146 compared to a run of 85261 for its local competitor, Neue Zürcher Zeitung (www.schweizermedien.ch, 21.8.2017, translated by the author).
} 
pendently of their surrounding context. (Callon, 1998:249)

The process of framing implies severing all sorts of connections (see Berndt and Boeckler, 2011:1060). However, Callon observes that framing is not fully detached from its surrounding context, since actors bring with them "cognitive resources as well as forms of behaviour and strategies which have been shaped and structured by previous experiences" (Callon, 1998:249). The whole process of framing is therefore "rooted in the outside world, in various physical and organizational devices. This is why framing puts the outside world in brackets, as it were, but does not actually abolish all links with it" (Callon, 1998:249). The relation between the outside world and the interiority is a rather complex entanglement or assemblage, since there is "an endless ramification of processes and contexts 'out-there' that are both necessary to what is 'in-here' and invisible to it" (Law, 2004:42). Such complex entanglements between "out-there" and "inhere" may also be found in processes like educational selection. In this way, the interests of schools ("in-here") are connected with public discourse ("out-there") on the issue of educational selection.

To link the in-here with the out-there of things, Callon suggested two dimensions of framing. The first assumes that "framing is the norm" and that "overflows are exceptions" (Callon, 1998:250). An empirical example can illustrate this theoretical argument. Before 2007, grammar schools in Zurich could autonomously select their future students. It was each school's responsibility to create, conduct, mark, and evaluate the entrance tests and permit as many students to the school as there were places. This seems at first glance to be a simple question of economic demand and supply. Unsurprisingly, the entrance examination tests and results varied from school to school. Each school used their own procedure to adjust the allocation of student places to their capacities. The in-here of school particularities set the frame for the out-there experienced by candidates seeking to enter the school.

However, the schools also had to apply the cantonal entrance requirements for Langzeitgymnasien: students were accepted if their test results in mathematics and German (shown as full, half, and quarter marks) averaged with their marks in mathematics and German from their final year in primary school to a score of 4.5 or better on a scale from 1 to 6. So, despite the schools' relative autonomy in selecting their future students according to the schools' needs and profiles, they also had to comply with regulations applying to all grammar schools in the canton of Zurich. The in-here-ness of school is legally subordinated to the Bildungsdirektion, which is constituted by many actors that are part of out-there. Furthermore, students in the canton of Zurich were also free to apply to and take the entrance test at whichever school they preferred. However, each student was allowed to apply and sit the test only once a year and at his or her preferred gram- mar school. Returning to the theoretical discussion above, the introduction of the ZAP in 2007 can be seen as establishing a new and formalized frame or "framing" (Callon, 1998:248) for educational selection. While the schools were still able to select their future students autonomously under the ZAP, potential advantages were thus bracketed and rendered invisible. Through the ZAP, all candidates actually sitting the test were made equal on the day of the examination, since there was one test for all at all schools. Nonetheless, candidates with excellent marks in year 6 of primary school were still "more equal"; their chances of succeeding were stronger, because the school marks and the test result were still required to reach an average of at least 4.5. However, how the marks from primary school are "produced" may vary greatly in detail, depending on such factors as the size, performance, and standards in each class; the assessment culture of the teacher; the teaching and evaluation standards of schools in catchments with diversely performing student bodies; and the knowledge and skills that students from various social and cultural backgrounds bring to class.

As the following example shows, framing actually means a reset and re-evaluation of established, invisible, powerful, unstable, social, and technical connections. Framing or reframing may therefore result in facilitating new arrangements and agencies of socio-material effects. The following example illustrates the notion of "flexibility" that is inherent in framing processes:

\section{The wondrous uplift of the marks before the central entrance examination (ZAP)}

Twelve-year old Luca scores an average of 4.5 in mathematics. In his school report, however, this is generously rounded up to 5.0. And here is why: when a student aspires to go to a grammar school after completing year 6 in the canton of Zurich, the student's marks in German and mathematics at primary school are averaged with their results in the central entrance examination (ZAP). What counts, in the end, is the average, which has to be 4.5 or better. Luca's parents and his primary teacher are well aware of the fact that this goal is almost out of reach with a 4.5 in the mathematics primary school report.

One consequence of this phenomenon is that those responsible for the entrance examination adjust to the generously rounded up marks in primary school reports by particularly severe marking of the entrance examinations. This results in a rather low average mark.

There is a vicious circle at work here. Grammar school teachers marking the entrance examinations presume that primary school teachers marking their students too generously and therefore judge the students' tests more strictly than they 
would do otherwise. Primary school teachers, on the other side, presume that grammar school teachers mark the entrance examinations very strictly and therefore round up the marks in the primary school report. This is a system of self-fulfilling prophecies in which the expected behaviour of the opposite party is enforced by one's own behaviour.

(newspaper article by Marius Huber, Tagesanzeiger 5 February 2015; translated, abbreviated, and slightly adapted by this paper's author)

This short newspaper article not only shows an individual case. In addition, his example illustrates the positive modification and adaptation of marks in primary school and the corresponding stricter evaluation of the ZAP tests by teachers at grammar school. Luca's case strikingly illustrates the framing of educational selection as a socio-technical assemblage, "a process of bundling, of assembling, or better of recursive self-assembling in which the elements put together are not fixed in shape, do not belong to a larger pre-given list but are constructed at least in part as they are entangled together" (Law, 2004:42).

Thus, predicting candidates' chances of passing on the basis of their entrance marks and their social and migratory backgrounds (see e.g. Kramer et al., 2009; Oelkers, 2008; Neuenschwander and Grunder, 2010) fails to acknowledge the hidden processes of translation, negotiation, and entanglements of aspects and sometimes playful agencies that are both social and material. Whereas Law emphasizes this notion of playfulness and the instability of assemblages, Deleuzian "socio-technical agencements" show two other points: first, an "arrangement of material, technical, logistical, legal, procedural, etc. elements and human beings; and second, this arrangement, this hybrid collective shapes agency, a capacity to act which may be individualized, but is more often distributed amongst various agents" (Berndt and Boeckler, 2011:1060, emphasis in original). In Luca's case, agency was distributed amongst teachers from primary school and grammar school, his own performance at school, test papers and evaluation sheets from school, the primary school headmaster backing the teacher's decision, the ZAP regulations and test, and his parents' support or insistence on his taking the ZAP test. Consequently, the distribution of agency by the ZAP enables a discussion of the socio-materialities, human and non-human actants, and agency arrangements that stabilize educational selection or formal schooling in general (see also Fenwick and Edwards, 2010, 2014).

To summarize this argument on framing and assembling: the introduction of the ZAP in 2007 was actually an important milestone in the formalization and legitimization of the selection process for secondary education within the canton of Zurich. The framing of the ZAP included rules and standards newly established by the Bildungsdirektion and legitimized by the cantonal parliament, the consent of the schools executing and responding to the results of the tests, and the aspiring students and their families following the new rules. The framing of the ZAP was introduced, formalized, and acknowledged by socio-material agents such as students, marks, regulations, quotas, and geographical differences. This system of educational selection provides a clear instance of the logic underlying Callon's argument that "framing is the norm (...) and overflows are exceptions which must be contained and channelled" (Callon, 1998:250).

What now happens to my analysis of educational selection when I approach the issue with Callon's second dimension of framing, which turns the first upside down? This counterargument claims that instead of framing, it is overflows that are the norm (see Callon, 1998:252).

The preceding paragraphs have sketched out some sort of "primary framework" (Goffman, 1974) for educational selection in Zurich. According to Callon, overflows are part and parcel of framing processes, because "framing implies the possibility of identifying overflows and containing them" (1998:248). Through the active interrelation of framing and overflowing, we understand framing as a "delicate and contested process, a process which can only be stabilized performatively, easily gets out of control, and is never complete" (Berndt and Boeckler, 2011:1060).

I argue that in addition to a self-stabilizing and selffulfilling framing of educational selection as a process inherent to a society that views itself as meritocratic, there is also an element of overflow in educational selection in Zurich. This overflow simultaneously stabilizes and contradicts the established selection network. This statement raises interesting questions: how is educational selection assembled, enacted, and performed? How can we grasp a thing that both acts and counteracts and both stabilizes and destabilizes at the same time? Callon $(1998,2007 \mathrm{a}, \mathrm{b})$ offers a theoretical framework to explain the particularities and contradictions that help to set up a forceful assemblage. In relation to educational selection, this is the core argument: framing may be conceptualized as a hybrid process consisting of framingand-overflowing and of enacting and performing (including acting against) the set of rules established by the frame. The most important constant in this frame is permanent change, because "orders only exist when actors enact them. And as there cannot be identical repetition, there is always a degree of instability, fuzziness, an irritation" (Berndt and Boeckler, 2011:1060-1061). The local context of educational selection in Zurich, with its framing and overflowing, fully exemplifies this theoretical argument.

I illustrate this point by returning to the empirical example of Luca. When the Bildungsdirektion enacted the ZAP by establishing a new legal and authoritative framework, the human and non-human actors involved in this framing started to perform the ZAP in different ways right from the start. This is apparent in Luca's example. Schools as institutional settings and teachers and administrators as ZAP executives differ in how they manage the test procedures within the standard- 
ized test guidelines. Further, the constant change within this framework is made even more apparent by the almost annual amendments to the ZAP procedure since its introduction in $2007^{7}$. I return to this argument about framing and overflowing in educational selection in the next chapter. There, I use a second empirical example, this time drawn from my data, to link the three theoretical concepts on which this article is founded. Before I do so, I introduce the concept of "fuzzy logic" and the empirical data.

\subsection{Fuzzy Logic}

This section elaborates the aspect of "fuzziness" by introducing another empirical example. The intent is to connect Callon's concept of framing and overflowing with Zadeh's fuzzy logic (Zadeh, 1989, 2015).

For 2 years shortly after its introduction (2008 and 2009), the obligatory test of the ZAP was accompanied by a second test, the Allgemeine Kognitive Fähigkeiten (general cognitive competencies - AKF) test. This voluntary test was designed by the Institute for Educational Evaluation at the University of Zurich. The test procedure had the students first do the ZAP test (comprising $60 \mathrm{~min}$ text production and $30 \mathrm{~min}$ text comprehension for the test result in German and a $60 \mathrm{~min}$ test in mathematics), then proceed to the AKF test, running another 45 min (with 60 questions that were divided into five sections with multiple choice, verbal, and non-verbal tasks). However, they were informed that the outcomes of the AKF test had no influence on their entrance into grammar schools. According to Moser and Berger (2010:4), this additional test was provided to answer three questions: first, did the results of the ZAP provide reliable results - did it pass the most intelligent and able students? Second, did the ZAP disadvantage intelligent students with a poor or migration social background? And third, could the results of the AKF and ZAP tests together provide a reliable prognosis of which students would pass the probationary period at grammar schools? The Bildungsdirektion hoped to further improve the quality of the central entrance examination by finding answers to these three questions.

A closer look at the local media coverage concerning the AKF test between its introduction (2008) and abolition (2010) together with subsequent accounts (e.g. in 2014) reveals interesting aspects.

\section{Argument 1: ZAP and AKF produce reliable test results}

The admittance procedure to grammar school is fair. The majority of the primary school marks have been reproduced in the entrance examination. This confirms the excellent work and assessments of

\footnotetext{
${ }^{7}$ For an example on changing regulations, see https: //www.zh.ch/dam/Portal/internet/news/mm/2012/050/Aufnahme_ Mittelschulen_Reglemente.pdf.spooler.download.1330586275647. pdf/Aufnahme_Mittelschulen_Reglemente.pdf (25.8.2017).
}

students by primary school teachers. Overall, highachieving students also did well in the AKF test. (Tagesanzeiger, 1 July 2009)

\section{Argument 2: Divergent test results between ZAP} and $A K F$

The most interesting figures are the numbers of those 12- and 13-year-old students who failed the central entrance examination. Among them, 49 were among the top $10 \%$ in the AKF test (...) and 35 of this failing cohort were boys. (Tagesanzeiger, 1 July 2009)

Argument 3: AKF test is not producing the expected results

There are no advantages for children speaking a foreign language, because compared to their German-speaking peers, they consistently achieved lower results. This applies to the entrance examination just as much as to the AKF test. (Tagesanzeiger, 1 July 2009)

Surprisingly, the Bildungsdirektion abandoned the AKF test. The reason given was that the test produced results that were not expected. (Tagesanzeiger, 15 July 2010)

Argument 4: AKF test was abolished because it produced the expected results

The results of the AKF test showed strong agreement with the results of the entrance examination procedure, especially the written tests. Consequently, the Bildungsdirektion decided in 2011 to do without any additional tests of this kind. (Tagesanzeiger, 25 October 2014)

This was the initial frame of the central examination procedure: when the AKF test was introduced in 2008 as a complimentary test to ZAP, it was initially seen as a tool to show whether able students from migration backgrounds were advantaged or disadvantaged by the central examination. However, the results of the test for 2 years revealed a different picture: the ZAP test did not disadvantage students with a migration background. A small group of 49 intelligent students ( 35 boys and 14 girls) in 2008 showed an extremely strong performance in the AKF test (they reached the top $10 \%$ of AKF test scores) but failed the ZAP test. The next year, the group of students whose AKF and ZAP test results were highly contradictory declined to 13 students. Unfortunately, the final AKF report (Moser and Berger, 2010) does not differentiate this group into girls and boys. In both years, this group of students was denied access to grammar school after year 6 of primary school. The numbers indicate that in 2008, it was mainly boys, presumably highly intelligent boys, who failed the entrance test. An evaluation of the AKF test by Moser and Berger (2010:28ff.) also demonstrated that the percentage of successful male ZAP candidates with high 
scores in AKF tests (top 20\%) who did not pass the probationary period at grammar schools was significantly higher than the equivalent figure for their female colleagues $(74 \%$ of that group were male in the 2008 cohort entering Langgymnasium, with similar results in 2009). The conclusion of the evaluation team implied a straightforward gender issue concerning the difference in results between ZAP and AKF. Moser and Berger stated that there is a gender correlation between candidates with high test scores and failing ZAP results, because boys were overrepresented in this group. They also reveal that boys achieved significantly better test results than girls (see Moser and Berger, 2010:29, 46). The report concluded that it would be mostly to the benefit of boys if a test evaluating the general cognitive abilities such as the AKF test were to be introduced to the ZAP procedure.

I would like to offer two different readings of the surprising outcomes and the subsequent abolishment of the AKF test. First, Zadeh introduced his ideas on fuzzy logic in the early 1960 s, but they did not attract much attention until the upsurge in computing, electronic engineering and artificial intelligence from the 1980s onwards. Zadeh describes the main ideas of fuzzy logic by attacking thinking in binary systems, which is at the core of the Cartesian scientific tradition:

Binarization - drawing a sharply defined boundary between two classes - is a deeply entrenched Cartesian tradition. What is not widely recognized is that this tradition has outlived its usefulness. One of the principal contributions of fuzzy logic is providing a basis for a progression from binarization to graduation, from binarism to pluralism, from black and white to shades of gray. (Zadeh, 2015:4)

The motivation for the Bildungdirektion's pilot study and the development of a supplementary intelligent test to the ZAP procedure was also based on a binary assumption: intelligent but disadvantaged students, the Bildungsdirektion assumed, might not be able to show their full potential in the ZAP test because of language problems, missing preparatory time, or poor opportunities due to lacking family budgets, knowledge, networks, or other difficulties. The argument followed a binary logic: the kids were highly talented (1) but were not able to show it and so failed the test (0). Interestingly, the final AKF evaluation report by Moser and Berger drew quite different pictures of the test results in ZAP and AKF with numerical categories (test results) and lexical (therefore approximate rather than exact) categorizations: "(d)epending on where the borderline between the categories actually is drawn - between the groups of very gifted, gifted and rather gifted students - the number of students who may be able to benefit from the AKF test could vary significantly" (Moser and Berger, 2010:23, translated by the

\footnotetext{
${ }^{8}$ In the report, the three categories were defined as follows: students in Group 1 were very capable but were unsuccessful (in the $\mathrm{AKF}$ test results, they were among the best $10 \%$ ); Group 2 were
}

author). This quote shows not only that the results varied but also the possible consequences of this, with many nonbinary shades of grey in between the lines. Some of these raise unexpected questions and the potential of socio-political controversies, such as the correlation between gender and test results. So, if we examine the two opposing statements from the media extracts above explaining that the AKF had been abolished either because it had or had not produced the expected results, we may initially be inclined to dismiss the newspaper reports simply as contradictory. However, the report actually provides support for both interpretations. Applying the basic argument of fuzzy logic, it is not a question of a binary set like true-false, but a more complex logic of grade membership in overlapping fuzzy sets or "cointensive indefinability" (Zadeh, 2015:6). Consequently, everything is a matter of degree in fuzzy logic (Zadeh, 1989:89). Unable to openly accept that fuzzy logic is an inherent element of educational selection, the Bildungsdirektion abolished the AKF test in 2010 and continued to rely solely on the results of the ZAP.

My second reading follows the argument of framing and overflowing in the preceding section. Here, the failing boys and girls did not fit, or overflowed, the ZAP structure and procedure in three aspects: first, they failed the ZAP test. Second, the calculation of the ZAP score (test results in mathematics and German and mathematics and German results in year 6 must average a mark of 4.5 or better) failed to pass these students, because their school marks were not good enough to compensate for their poor test results. And third, this showed that their primary teachers also failed to recognize their high potential, although the marks for mathematics and German in the primary school report in year 6 are estimated to be overrated by most primary teachers, as the example of Luca above shows. Rather than labelling or stigmatizing these boys and girls as overflow, I would argue that the $\mathrm{ZAP}$ and the accompanying AKF test enacted and performed an overflow on this group of students. The testing machinery could not appropriately account for this problem; it was not designed to cope with these contradictory elements and actors. What the Bildungsdirektion did to solve this dilemma was to abolish the AKF test altogether. As a consequence, no more problematic or irritating "data" (or crucial personal experiences and consequences for highly gifted yet failing students) have been produced since 2009 .

Two interesting processes are at work here: first, framing and overflowing and, second, enacting and performing. The ZAP/AKF example illustrates how ambivalent the play is between these hybrid connections. Interestingly, the Bildungsdirektion abolished the AKF test with the justification that the "test produced different results than were expected" (Tage-

capable but were unsuccessful (in the AKF test results, they were among the best 11 to $20 \%$ ); Group 3 were quite capable but were unsuccessful (in the AKF test results, they were among the best 21 to $30 \%$; see Moser and Berger 2010:22-23). 
sanzeiger, 15 July 2010). The media coverage focused on the overflows, the "irritations, disjunctures and paradoxes surfacing when heterogeneous actors practically enact the model" (Berndt and Boeckler, 2011:1058). Conversely, reporting in 2014 followed the argument that the test had been abolished because of its strong correlation with the ZAP results. Here, the coverage follows the argument of framing or stabilizing the ZAP assemblage, where the frame is trying to shape the outside according to the internal logic of the model. There is no right or wrong, since both processes are at work, stabilizing and destabilizing, doing and undoing. In the end, it was the test that was turned into an enacting and performing procedure with varying interpretations, because the test produced not only exactly the expected but also very different results than were expected from the Bildungsdirektion, according to the media coverage. This logic is fuzzy indeed. At the same time, the Bildungsdirektion enacted and performed a readjustment and stabilization of the ZAP framework by abolishing the AKF test because the overflowing effects of the established frame were too irritating to accept.

\section{Conclusion}

Starting with conceptual considerations from ANT and assemblage theories, this article has illuminated how an approach inspired by socio-material thinking can make novel contributions to analysing educational selection. In the context of educational selection, socio-material approaches can help to show "how such assemblages can be unmade as well as made, and how counter-networks or alternative forms and spaces can take shape and develop strength" (Fenwick et al., 2011:97).

Following this line of thought, the central entrance examination (ZAP) for grammar schools in Zurich was considered an assemblage of material, non-material, and human elements that effectively produce or frame a socially accepted form of selection. It is the ZAP that assembles humans (e.g. teachers, experts, students) and non-humans (e.g. statistical data, evaluation sheets, examination questions) in a way that provides a constant frame for the sake of stabilizing the procedures of an annual test machinery.

The theoretical argument of the article used the concepts of framing and overflowing (Callon, 1998) to elaborate a new and different reading of educational selection processes. I argued that inherent in these processes of framing are also aspects of overflowing. On one side, human and non-human network effects try to stabilize the complex assemblage and provide a coherent framing. However, the other side cannot be detached or denied: the irritations, disjunctures, and paradoxes - in short, the overflowings. These counter-narratives surface when heterogeneous actors enact the ZAP frame. The examples of Luca and his marks (and the wondrous rise in the marks in year 6) or the abolition of the AKF test illustrated how framings and overflowings are mutually entwined within enacting and performing the ZAP. Another reading of Luca's example introduced fuzzy logic as a way to examine educational selection beyond binary dichotomies. I argued that the test procedures and results of the ZAP and AKF tests may be understood in terms of a complex logic of membership depending on what the categories represent, how the test results are interpreted, and where the borderlines between pass and fail are actually drawn. Perhaps understandably, the Bildungsdirektion in Zurich was unable to openly accept that fuzzy logic is an inherent element of educational selection. However, the almost annual amendments to the test procedure themselves provide strong evidence that the matter of degree within educational selection remains an active issue for educational administrators and their application of an inherent fuzzy logic of educational selection. There is no doubt that the empirical example used in this paper as a starting point is quite a local issue. However, from the local issues raised by ZAP, we may return to the more general debates in educational research discussed at the beginning of the article, such as inequalities, educational selection, and transitions in public schooling. Using these arguments to link young people's geographies with geographies of education and learning shows how to build bridges not only between international and national educational discourse and local practice but also between academic research and a socio-political engagement that cares about young people's educational realities and futures.

An example from Zurich illustrates this point in more detail. Even years after the introduction of ZAP, Regine Aeppli did not tire of repeating the initial motivation for the initiative.

I am fully committed to the right to equal chances in education, but this right may continue to be a constant challenge forever. (Regine Aeppli in an interview with Tagesanzeiger, 5 May 2015, translated by the author)

Despite the good intentions that initiated the introduction of the ZAP, comparative analysis before and after its introduction shows no significant change to the imbalance in access rates to grammar schools. Young people from wealthy backgrounds are still more likely to attend grammar schools than their peers from socially disadvantaged or migration backgrounds (Gymnasialer Mittelschulbericht, 2014:33). So, we may read Regine Aeppli's statement with feelings of consternation or even resignation. The ideal of equal opportunities in education - and in society more generally - may indeed remain a constant challenge and a socio-political ideal. Even well-meant initiatives that try to work against existing inequalities in education and educational selection may ultimately reproduce old and new forms of inequalities. However, criticizing existing procedures and structures is easier than getting involved in educational realpolitik. Accepting this dilemma, I would argue that we should not discourage initiatives that strive for a more just realization of society 
but as academics and critical thinkers seek a more active part in this process. Thus, in her mandate as head of the Bildungsdirektion, Regine Aeppli chose to continue her active engagement in education. She supported small projects and initiatives with realistic targets. One of these projects facilitated a local programme, called ChaGALL (Chancengerechtigkeit durch Arbeit an der Lernlaufbahn), at a private grammar school in a wealthy Zurich neighbourhood trying to make a difference to a small number of children (usually about 11-14 students per year) from migrant families (Berger et al., 2015:6). Starting in 2008, this programme has offered cost-free training for the entrance examination to a selected number of intellectually gifted students. The Bildungsdirektion hoped that the programme would not only help these students to better prepare for and pass the ZAP test. Successful candidates were also offered personal long-term mentors on their way through grammar school. The evaluation of the programme (referring to the school years 2008/2009 to 2013/2014) documented the positive effects on the candidates' chances of passing the ZAP: $70 \%$ of the 74 participating youth in these 6 school years altogether were successful in the ZAP and only five students had to leave the grammar school during the probationary period. In addition, the success rate of the project has increased continuously, from $42 \%$ in 2008/2009 to $85 \%$ in 2013/2014 (Berger et al., 2015).

Encouraged by the positive results of ChaGALL, Regine Aeppli promoted a broader initiative that introduced a strong recommendation to all Schulgemeinden (i.e. school communities) in the canton to offer training courses to gifted and motivated students who intend to sit the next ZAP. Since 2012, most Schulgemeinden have been offering free preparatory courses to students with high aspirations at their local primary schools. These courses usually offer two extra lessons per week throughout the school term preceding the ZAP in March.

Recent trends in educational research and politics show that neoliberal, meritocratic thinking has permeated through to governance of public education and schooling (e.g. Gorur, 2014; Kulz, 2015). Using a socio-material perspective on educational selection, I intended to offer a constructive counterpoint to such trends, starting from a local case study in Zurich. Studies using ANT and assemblage theory are helpful when moving beyond the framing model with stabilizing effects and irritating overflows. The focus shifts towards new questions, such as how educational selection is actually performed and enacted by human and non-human actors. It is this change in perspective that can make a difference because it may give us an idea not only why but also how we can actually become engaged in education and politics. In times of harsh budget cuts for youth-related institutions, enforced accountability of schools, and growing support for the neoliberal restructuring of education (e.g. Hörschelmann, 2018; Horton, 2016; Kulz, 2013), it is important not only to point out that academics can put implicit activism into practice. We can actually become ourselves engaged in projects of "small acts, kind words and not too much fuss" that try to make a difference for young people of various abilities and aspirations (Horton and Kraftl, 2009).

Data availability. The empirical sources as well as the methodology used to generate the findings presented in this paper have been explained in Sect. 4. For further inquiries about the data, its processing, coding, and analysis, please contact the author.

Competing interests. The author declares that she has no conflict of interest.

Acknowledgements. I would like to thank the working group "Geographie, Jugend und Bildung" and my colleague Sara Landolt at the Department of Geography at the University of Zurich for their helpful comments and an inspiring debate on an earlier version of this paper. Also, I would like to thank the reviewers and Myriam Houssay-Holzschuch for their thoughtful and constructive feedbacks.

Edited by: Myriam Houssay-Holzschuch

Reviewed by: three anonymous referees

\section{References}

Baeriswyl, F.: Chancengerechtigkeit und Diskriminierung beim Übertritt in die Sekundarstufe I: Schulische Selektionsmodelle im Vergleich, in: EQITY -Diskriminierung und Chancengleichheit im Bildungswesen. Migrationshintergrund und soziale Herkunft im Fokus, edited by: Haenni, A., Bern, EDK, 73-82, 2015.

Bauer, I.: Approaching Geographies of Education differANTly, Children's Geographies, 13, 620-627, 2015.

Baumann, R.: 3536 Schüler lösten die gleichen Rechenaufgaben, Tagesanzeiger, 25.5.2007.

Baumert, J., Maaz, K., and Trautwein, U.: Bildungsentscheidungen, Wiesbaden, VS Verlag für Sozialwissenschaften, 2009.

Becker, R.: Soziale Ungleichheit im Schweizer Bildungssystem und was man dagegen tun könnte, in: Schulübergang und Selektion: Forschungsbefunde, Praxisbeispiele, Umsetzungsperspektiven, edited by: Neuenschwander, M. P. and Grunder, H.-U., Zürich: Rüegger, 91-108, 2010.

Becker, R. and Hadjar, A.: Meritokratie - Zur gesellschaftlichen Legitimation ungleicher Bildungs-, Erwerbs- und Einkommenschancen in modernen Gesellschaften, in: Lehrbuch der Bildungssoziologie, edited by: Becker, R., Wiesbaden, VS Verlag für Sozialwissenschaften, 35-59, 2009.

Becker, R. and Lauterbach, W. (Eds.): Bildung als Privileg? Erklärungen und Befunde zu den Ursachen der Bildungsungleichheit, Wiesbaden, 2004.

Beighton, C.: Assessing the mess: challenges to assemblage theory and teacher education, International Journal of Qualitative Studies in Education, 26, 1293-1308, 2012.

Berger, S., Meiler, L., and Moser, U.: Evaluation des Programms Chancengerechtigkeit durch Arbeit an der Lernlauf- 
bahn, Kurzbericht zuhanden der Projektleitung, Institut für Bildungsevaluation, UZH, 2015.

Berndt, C. and Boeckler, M.: Performative regional (dis)integration: transnational markets, mobile commodities, and bordered NorthSouth differences, Environ. Plann. A, 43, 1057-1078, 2011.

Bildungsdirektion Kanton Zürich: Die Schulen im Kanton Zürich 2000/2001, 2001

Bildungsdirektion Kanton Zürich: Gymnasialer Mittelschulbericht 2014, 2015.

Bildungsdirektion Kanton Zürich: Die Schulen im Kanton Zürich 2016/2017, 2017.

Bourdieu, P. and Passeron, J.-C.: Reproduction in Education, Society and Culture, Los Angeles, Sage, 2011 (1970).

Boudon, R.: Education, opportunity, and social inequality: Changing prospects in Western society, New York, 1974.

Brake, A. and Büchner, P.: Bildung und soziale Ungleichheit. Eine Einführung, Stuttgart, Verlag W. Kohlhammer, 2012.

Brown, G., Kraftl, P., Pickerill, J., and Upton, C.: Holding the future together: towards a theorisation of the spaces and times of transition, Environ. Plann. A, 44, 1607-1623, 2012.

Bundesamt für Statistik: Maturitätsquote, available at: https://www. bfs.admin.ch/bfs/de/home/statistiken/bildung-wissenschaft/ bildungsindikatoren/bildungssystem-schweiz/themen/ abschluesse/maturitaetsquote.assetdetail.2421483.html, last access: 15 August 2017a.

Bundesamt für Statistik: Bildungsabschlüsse. Entwicklung, available at: https://www.bfs.admin.ch/bfs/de/home/statistiken/ bildung-wissenschaft/bildungsabschluesse/sekundastufe-II. assetdetail.2950608.html, last access: 15 August 2017b.

Butler, T. and Hamnett, C.: The Geography of Education: Introduction, Urban Studies, 44, 1161-1174, 2007.

Collins, D. and Coleman, T.: Social Geographies of Education: Looking Within, and Beyond, School Boundaries, Geography Compass, 2, 281-299, 2008.

Callon, M.: Some elements of a sociology of translation: domestication of the scallops and the fishermen of St Brieuc Bay, in: Power, action and belief: a new sociology of knowledge?, edited by: Law, J., London, Routledge, 196-223, 1986.

Callon, M.: An essay on framing and overflowing: economic externalities revisited by sociology. The Sociological Review, Malden, Blackwell, 1998.

Callon, M.: An Essay on the Growing Contribution of Economic Markets to the Proliferation of the Social, Theor. Cult. Soc., 24, 139-163, 2007a.

Callon, M.: What Does It Mean to Say That Economics Is Performative?, in: Do Economists Make Markets? On the Performativity of Economics, edited by: MacKenzie, D., Muniesa, F., and Siu, L., Princeton University Press, 311-357, 2007b.

Ditton, H.: Effekte der sozialen Herkunft auf die Schulformwahl beim Übergang von der Primar- in die Sekundarstufe. Schulübergang und Selektion, in: Schulübergang und Selektion: Forschungsbefunde, Praxisbeispiele, Umsetzungsperspektiven, edited by: Neuenschwander, M. P. und Grunder, H.-U., Zürich, Rüegger Verlag, 35-59, 2010.

Ecclestone, K., Biesta, G., and Hughes, M.: Transitions in the lifecourse, in: Transitions and Learning through the Lifecourse, edited by: Ecclestone, K., Biesta, G., and Hughes, M., New York, Routledge, 1-15, 2010.
Eberle, F.: "Die heutige Maturaquote ist ausreichend", Neue Zürcher Zeitung am Sonntag, Teil "Hintergrund", Interview, 3.3.2013, S. 9, 2013.

Fenwick, T. and Edwards, R.: Actor-Network Theory in Education, London and New York, Routledge, 2010.

Fenwick, T. and Edwards, R.: Networks of knowledge, matters of learning, and criticality in higher education, Higher Education, 67, 35-50, 2014.

Fenwick, T., Edwards, R., and Sawchuck, P.: Emerging Approaches to educational research: Tracing the socio-material, London, Routledge, 2011.

Fibbi, R., Lerch, M., and Wanner, P.: School qualifications of children of immigrant descent in Switzerland, in: New Dimensions of Diversity: The Children of Immigrants in North America and Western Europe, Alba, R. and Waters, M., New York, New York University Press, 110-134, 2011.

Fox, S.: Contexts of teaching and learning: An actor-network view of the classroom, in: Rethinking Contexts for Learning and Teaching: Communities, activities and networks, edited by: Edwards, R., Biesta, G., and Thorpe, M., London and New York, Routledge \& Francis Group, 31-43, 2009.

Goffman, E.: Frame Analysis. An Essay on the Organization of Experience, Hanover and London, University Press of New England, 1974.

Gorur, R.: ANT on the PISA Trail: Following the statistical pursuit of certainty, Educational Philosophy and Theory, 43, 76-93, 2011.

Gorur, R.: Producing calculable worlds: education at a glance. Discourse: Studies in the Cultural Politics of Education, 36, 578595, 2014.

Grant, T.: The complexity of aspiration: the role of hope and habitus in shaping working-class young people's aspirations to higher education, Children's Geographies, 15, 289-303, 2017.

Hamnett, C. and Butler, T.: "Geography matters: The role distance plays in reproducing educational inequality in East London.”, T. I. Brit. Geogr. NS, 36, 479-500, 2011.

Harris, R.: Geographies of transition and the separation of lower and higher attaining pupils in the move from primary to secondary school in London. T. I. Brit. Geogr. (Virtual Issue), 2012.

Henz, U. and Maas, I.: Chancengleichheit durch Bildungsexpansion?, Kölner Z. Soziol. Soz., 47, 605-633, 1995.

Hollingworth, S., Williams, K., Jamieson, F., and Beedell, P.: Social and educational inequalitites in English state schools: exploring the understandings of urban white middle-class children, in: Geographies of Children, Youth and Families, edited by: Holt, L., London and New York, Routledge, 250-264, 2011.

Holloway, S. L., Brown, G., and Pimlott-Wilson, H.: Editorial introduction: Geographies of education and aspiration, Children's Geographies, 9, 1-5, 2011.

Hörschelmann, K.: Theorising life transitions: geographical perspectives, Area, 43, 378-383, 2011.

Hörschelmann, K.: Unbound emotional geographies of youth transitions, Geogr. Helv., in press, 2018.

Horton, J.: Anticipating service withdrawal: young people in spaces of neoliberalisation, austerity and economic crisis, T. I. Brit. Geogr., 41, 349-362, 2016.

Horton, J. and Kraftl, P.: Not just growing up, but going on: Materials, Spacings, Bodies, Situations, Children's Geographies, 4, 259-276, 2006. 
Horton, J. and Kraftl, P.: Small acts, kind words and "not too much fuss": Implicit activism, Emot. Space Soc., 2, 14-23, 2009.

Imdorf, C.: Rechtfertigungsordnungen der schulischen Selektion, in: Öffentliche Erziehung revisited, edited by: Amos, S. K., Meseth, W., and Proske, M., Wiesbaden, VS Verlag für Sozialwissenschaften, 225-245, 2011.

Jeffrey, C. and Dyson, J. (Eds.): Telling Young Lives. Portraits of Global Youth, Philadelphia, Temple University Press, 2008.

Johnson-Hanks, J.: On the Limits of Life Stages in Ethnography: Toward a Theory of Vital Conjunctures, Am. Anthropol., 104, 865-880, 2002.

Jöns, H.: Dynamic hybrids and the geographies of technoscience: discussing conceptual resources beyond the human/non-human binary, Soc. Cult. Geogr., 7, 559-580, 2006.

Kramer, R.-T., Helsper, W., Thiersch, S., and Ziems, C. (Eds.): Selektion und Schulkarriere. Kindliche Orientierungsrahmen beim Übergang in die Sekundarstufe I. Wiesbaden, Verlag für Sozialwissenschaften, 2009.

Krippendorff, K.: Content Analysis, London, Sage, 2013.

Kulz, C.: "Structure liberates?": mixing for mobility and the cultural transformation or "urban children" in a London academy, Ethnic Racial Stud., 37, 685-701, 2013.

Kulz, C.: Heroic heads, mobility mythologies and the power of ambiguity, Brit. J. Sociol. Educ., 38, 85-104, https://doi.org/10.1080/01425692.2015.1044071, 2015.

Kutter, A. and Kantner, C.: Corpus-based content analysis: a method for investigating news coverage on war and intervention, International Relations Online Working Paper Series, 1, 1-38, 2012.

Latour, B.: On actor-network theory. A few clarifications, Soziale Welt, 47, 369-381, 1996.

Law, J.: After ANT: complexity, naming and topology, in: Actor Network Theory and after, edited by: Law, J. and Hassard, J., Oxford and Malden, Blackwell, 1-14, 1999.

Law, J.: After Method, Mess in social science research, Oxon, Routledge, 2004

Maaz, K., Hausen, C., McElvany, N., and Baumert, J.: Stichwort: Übergänge im Bildungssystem, Z. Erziehungswiss., 3, 299-327, 2006.

Maaz, K. and Neumann, M.: Mechanismen schulischer Selektion, in: Neuenschwander, M. P., Selektion in Schule und Arbeitsmarkt, Zürich, Rüegger, 21-40, 2014.

Mayring, P.: Qualitative Inhaltsanalyse: Grundlagen und Techniken, Weinheim, Beltz, 2010.

Meyer, H.-D. and Benavot, A. (Eds.): PISA, Power, and Policy. The emergence of global educational governance, Oxford, Symposium Books, 2013.
Mills, S. and Kraftl, P. (Eds.): Informal Education, Childhood and Youth. Geographies, Histories, Practices, Bastingstoke, palgrave macmillan, 2014.

Morrow, V.: Troubling transitions? Young people's experiences of growing up in poverty in rural Andhra Pradesh, India, J. Youth Stud., 16, 86-100, 2013.

Moser, U. and Berger, S.: Zur Bedeutung eines fächerübergreifenden Tests für den Übertritt in die Gymnasien des Kantons Zürich, Institut für Bildungsevaluation, UZH, 2010.

Neuenschwander, M. P. (Ed.): Selektion beim Übergang in die Sekundarstufe I und in den Arbeitsmarkt im Vergleich, Selektion in Schule und Arbeitsmarkt, Zürich, Rüegger, 63-97, 2014.

Neuenschwander, M. P. and Grunder, H.-U. (Eds.): Schulübergang und Selektion: Forschungsbefunde, Praxisbeispiele, Umsetzungsperspektiven, Zürich, Rüegger, 2010.

Oelkers, J.: Die Qualität der Schweizer Gymnasien, Bern, hip, 2008.

Punch, S.: Youth transitions and interdependent adult-child relations in rural Bolivia, J. Rural Stud., 18, 123-133, 2002.

Rautio, P.: Children who carry stones in their pockets: on autotelic material practices in everyday life, Children's Geographies, 11, 394-408, 2013.

Schneebli, D.: Aeppli lanciert eine Reform der Gymnasien, Tagesanzeiger, 12.1.2007.

Schneider, S. L. and Tieben, N.: A healthy sorting machine? Social inequality in the transition to upper secondary education in Germany, Oxford Rev. Educ., 37, 139-166, 2011.

Schreier, M.: Qualitative Content Analysis, in: The SAGE Handbook of Qualitative Data Analysis, edited by: Flick, U., London, Sage, 170-183, 2012.

Skelton, T.: Research on Youth Transitions: Some Critical Interventions, in: Young People in Risk Society: The restructuring of youth identities and transitions in late modernity, edited by: Cieslik, M. and Pollock, G., Aldershot, Burlington, Ashgate, 100116, 2002.

SKBF: Bildungsbericht Schweiz 2014, Aarau, Schweizerische Koordinationsstelle für Bildungsforschung (SKBF), 2014.

Valentine, G.: Bondary Crossings: Transitions from Childhood to Adulthood, Children's Geographies, 1, 37-52, 2003.

Vasarik Staub, K.: Die Übergangsphase von der Primarschule ins Gymnasium aus Elternsicht. Wiesbaden: Springer VS, 2015.

Verran, H.: Staying true to the laughter in Nigerian classrooms, in: Actor Network Theory and After, edited by: Law, J. and Hassard, J., London, Blackwell, 136-155, 1999.

Zadeh, L. A.: Knowledge Representation in Fuzzy Logic, IEEE T. Knowl. Data En., 1, 89-100, 1989.

Zadeh, L. A.: Fuzzy logic - a personal perspective, Fuzzy Set. Syst., 281, 4-20, 2015. 